\title{
Simulation of a GaP/ Si Heterojunction Thin Film Solar Cell on Glass Substrate
}

\author{
K. A. S. M. Ehteshamul \\ Haque \\ Department of Electrical and \\ Electronic Engineering, Islamic \\ University of Technology \\ Board Bazar, Gazipur-1704, \\ Bangladesh
}

\author{
Muhtadi Quyed \\ Choudhury \\ Department of Electrical and \\ Electronic Engineering, Islamic \\ University of Technology \\ Board Bazar, Gazipur-1704, \\ Bangladesh
}

\author{
Tahmid Nahian Bin \\ Quddus \\ Department of Electrical and \\ Electronic Engineering, Islamic \\ University of Technology \\ Board Bazar, Gazipur-1704, \\ Bangladesh
}

\begin{abstract}
This work presents a 1D simulation of light J-V characteristics of a GaP/ Si heterojunction thin film solar cell on glass substrate. The device is composed of a GaP/ Si n-p heterojunction, where the p-type $\mathrm{Si}$ layer serves as the absorber. A heavily doped p-type Si layer is used between the absorber and the substrate as a Back Surface Field (BSF) layer. The obtained results show slight improvement in shortcircuit current density $\left(\mathrm{J}_{\mathrm{sc}}\right)$ and efficiency, compared to the present thin film poly-Si solar cells fabricated on glass substrate. At 1 sun, under AM1.5G, the open-circuit voltage $\left(\mathrm{V}_{\mathrm{oc}}\right)$ and the short-circuit current density $\left(\mathrm{J}_{\mathrm{sc}}\right)$ were obtained as $0.5582 \mathrm{~V}$ and $28.42 \mathrm{~mA} / \mathrm{cm}^{2}$, respectively. With a fill factor of 0.8274 , the efficiency was calculated as $13.83 \%$. Afterwards, a number of thin film cell designs were proposed, with corresponding simulation outcomes. Besides this, saturation in short-circuit current density $\left(\mathrm{J}_{\mathrm{sc}}\right)$ and open-circuit voltage $\left(\mathrm{V}_{\mathrm{oc}}\right)$ with increasing absorber layer thickness was illustrated, in light of relevant simulation results.
\end{abstract}

\section{Keywords}

thin-film solar cell, heterojunction, window layer, glass substrate, short-circuit current density, open-circuit voltage.

\section{INTRODUCTION}

\subsection{Research Outlines}

Dual junction solar cells, using a top cell of $\mathrm{GaP}$ homojunction, and a bottom cell of Si homojuntion, has been developed with fairly high efficiency and improved performance in extended temperature range [1]. The drawback of multijunction photovoltaic cells is these cells are very costly, which inhibits their use in terrestrial applications [2]. The lattice mismatch between $\mathrm{Si}$ and $\mathrm{GaP}$ is very small $(0.37 \%)$, which suggests that the epitaxial growth of $\mathrm{GaP}$ on $\mathrm{Si}$ can be accomplished with negligible amount of dislocation density and strain [3]. Considering these issues, this work proposes a solar cell involving a GaP/Si n-p heterojunction, where the n-type GaP layer serves as a window layer. Window layer should be a high bandgap material, so that it allows maximum number of photons to reach the absorber. Besides this, a high-bandgap window layer reduces the cell's series resistance, and improves the open-circuit voltage [4]. Moreover, using a window layer between the absorber and the metal contact reduces the recombination of minority carriers at the metal-semiconductor interface [5].GaP has an indirect bandgap of $2.26 \mathrm{eV}$ [6], which makes it a good choice as a window for Si solar cells. In this work, the window layer has been kept very thin $(10 \mathrm{~nm})$ and heavily n-doped $\left(10^{18} \mathrm{~cm}^{-}\right.$ $\left.{ }^{3}\right)$ for improved performance [7-9]. Critical layer thickness for epitaxial growth, with a lattice mismatch of $0.37 \%$, is around $40 \mathrm{~nm}$ [10]. So, for the growth of a $10 \mathrm{~nm} \mathrm{GaP}$ layer on $\mathrm{Si}$, the issues of interface defects and strain can be ignored.

The absorber layer (p-type c-Si) plays the vital role in photon absorption and generation of electron-hole pairs. The doping concentration for the layer is kept at $10^{16} \mathrm{~cm}^{-3}$, while the layer thickness is taken as $2 \mu \mathrm{m}$. A thicker base can result in better absorption and performance, but this thickness value is chosen for a thin film cell design. A heavily doped $\left(10^{18} \mathrm{~cm}^{-3}\right)$ p-type Si layer $(1 \mu \mathrm{m})$ is used between the absorber and the glass substrate. This layer introduces a potential barrier to reduce surface recombination of minority carriers from the absorber at the semiconductor-glass interface [11]. Fig. 1 shows a schematic diagram of the device.

The reason behind choosing glass substrate is its low cost and high mechanical strength. One drawback of glass substrate is its low thermal stability, which is a bar to high-temperature growth of device layers. However, this problem can be solved by using borosilicate glass, which allows deposition at a temperature of around $1000^{\circ} \mathrm{C}$, or even higher [12].

\subsection{About the software}

All the simulations conducted for this work were done by Adept [13]. It is a 1D simulation tool, which was developed by Jeff Gray and Michael McLennan from Purdue University in 2008. This software can simulate the electrical characteristics of heterostructured semiconductor devices. It solves Poisson's equation, coupled with the hole and electron continuity equations in one spatial dimension for semiconductor devices. It was originally designed to model solar cells fabricated from a wide variety of materials. With this software, dark I-V characteristics, light I-V characteristics and spectral response of solar cells (or any other two-terminal device) can be obtained. Moreover, many internal parameters (carrier density, carrier velocity, electric field) can be plotted against device length. For simulating different device characteristics, values of required material parameters (band gap, mobility, thickness, doping level etc.) are given as inputs by the user. Devices, fabricated from a wide range of semiconducting materials, for which these parameters are known, can be modeled by the software. 


\section{METHODOLOGY}

In order to conduct the simulations, values of different structural, electrical and optical properties of the layer materials were required. Basic parameters of Si (bandgap, lattice constant, infrared refractive index, dielectric constant etc.) were taken from [6]. Electron and hole mobility values of p-type $\mathrm{Si}$, corresponding to the doping levels at the absorber and the BSF layer, were taken from [14]. Minority carrier lifetime in p-type $\mathrm{Si}$ (at these doping levels) was acquired from [15]. Absorption parameters for Si were calculated from the absorption coefficient graph for $\mathrm{Si}$, obtained from [16].

Values of basic parameters of $\mathrm{GaP}$ (bandgap, lattice constant, infrared refractive index, dielectric constant etc.) were taken from [6]. Minority carrier lifetime for heavily doped n-type $\mathrm{GaP}$ was also taken from [6]. The electron and hole mobility data for n-type $\mathrm{GaP}$, with a doping density of $10^{18} \mathrm{~cm}^{-3}$, were taken from [17]. Values of different parameters are listed in table 1 .

Table 1: Default values of device parameters

\begin{tabular}{|l|l|l|l|l|l|l|}
\hline $\begin{array}{l}\text { Layer } \\
\text { Material }\end{array}$ & $\begin{array}{l}\text { Band } \\
\text {-gap } \\
(\mathrm{eV})\end{array}$ & $\begin{array}{l}\text { Dielectric } \\
\text { Constant }\end{array}$ & $\begin{array}{l}\text { Refrac- } \\
\text { tive } \\
\text { Index }\end{array}$ & $\begin{array}{l}\text { Electron } \\
\text { Mobility } \\
\left(\mathrm{cm}^{2} / \mathrm{V}-\mathrm{s}\right)\end{array}$ & $\begin{array}{l}\text { Hole } \\
\text { Mobility } \\
\left(\mathrm{cm}^{2} / \mathrm{V}-\mathrm{s}\right)\end{array}$ & $\begin{array}{l}\text { Minority } \\
\text { Carrier } \\
\text { Lifetime } \\
(\mathrm{s})\end{array}$ \\
\hline $\begin{array}{l}\text { GaP } \\
\text { (Window) } \\
(\mathrm{n}-\mathrm{-type}, \\
\left.1^{18} \mathrm{~cm}^{-3}\right)\end{array}$ & 2.26 & 11.1 & 3.02 & 150 & 150 & $1 \times 10^{-6}$ \\
\hline $\begin{array}{l}\mathrm{Si} \\
(\text { Absorber }) \\
(\mathrm{p}-\mathrm{type}, \\
\left.10^{16} \mathrm{~cm}^{-3}\right)\end{array}$ & 1.12 & 11.7 & 3.42 & 1200 & 400 & $1 \times 10^{-6}$ \\
\hline $\begin{array}{l}\mathrm{Si} \\
(\mathrm{BSF} \text { Layer }) \\
(\mathrm{p}-\mathrm{type},\end{array}$ & 1.12 & 11.7 & 3.42 & 1000 & 300 & $1 \times 10^{-7}$ \\
$\left.10^{18} \mathrm{~cm}^{-3}\right)$ & & & & & & \\
\hline
\end{tabular}

AM1.5G solar spectrum was considered as the input irradiance in the simulation code, and a concentration level of 1 sun (no concentrator used) was taken. After conducting the simulation, light $\mathrm{J}-\mathrm{V}$ characteristics curve was obtained, which gave the values of short circuit current density $\left(\mathrm{J}_{\mathrm{sc}}\right)$ and open-circuit voltage $\left(\mathrm{V}_{\mathrm{oc}}\right)$. Fill factor $(\mathrm{FF})$ was calculated using equation (1), obtained from [18].

$$
F F=\frac{\text { Voen }-\ln (\text { Vocn }+0.72)}{\text { Vocn+1 }}
$$

Where,

$$
V O C n=\left(\frac{q}{n k T}\right) V o c
$$

Here,

$\mathrm{V}_{\mathrm{oc}}=$ Open-circuit voltage (in Volt)

$\mathrm{n}=$ Ideality factor (taken as 1 )

$\mathrm{q}=$ Charge of an electron $=1.6 \times 10^{-19}$ Coulomb

$\mathrm{k}=$ Boltzmann constant

$\mathrm{T}=$ Temperature in $\mathrm{K}$ (taken as $300 \mathrm{~K}$ )
With the short circuit current density $\left(\mathrm{J}_{\mathrm{sc}}\right)$, open-circuit voltage $\left(\mathrm{V}_{\mathrm{oc}}\right)$ and fill factor $(\mathrm{FF})$ being known, the efficiency was calculated using equation (3).

$$
H=\frac{\text { VocxjsexpF }}{E} \times 100 \%
$$

Where,

$\mathrm{E}=$ Input solar irradiance (taken as $1000 \mathrm{~W} / \mathrm{m}^{2}$ )

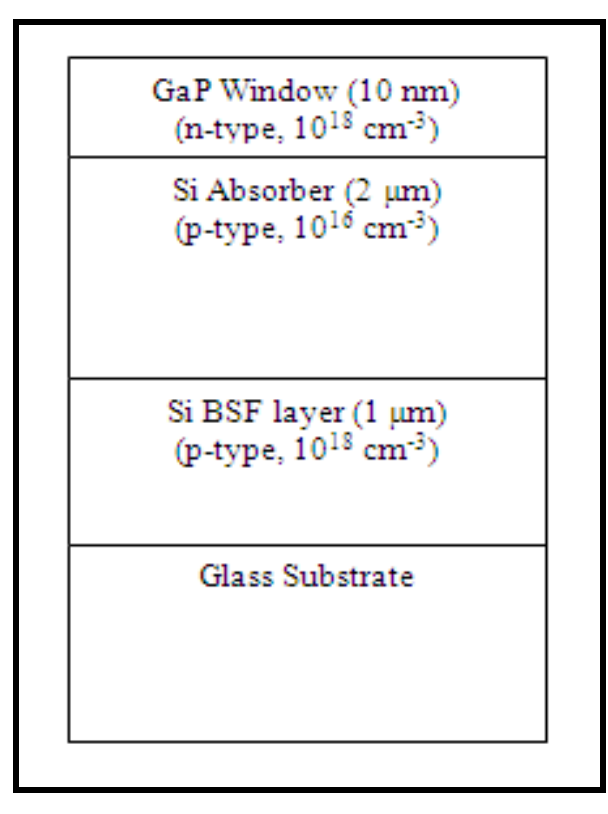

Fig. 1 Schematic diagram of the solar cell

\section{RESULTS AND DISCUSSION}

Figure 2 shows the light $\mathrm{J}-\mathrm{V}$ characteristics curve for the device of figure 1 , while figure 3 shows the energy band diagram of the device.

From figure 2, the short circuit current density $\left(\mathrm{J}_{\mathrm{sc}}\right)$ and the open-circuit voltage $\left(\mathrm{V}_{\mathrm{oc}}\right)$ are obtained as $28.42 \mathrm{~mA} / \mathrm{cm}^{2}$ and $0.5882 \mathrm{~V}$, respectively. It is to be noted that this short-circuit current density is slightly higher, compared to the present polycrystalline and nanocrystalline Si thin film solar cells on glass substrate $[19,20]$. With a fill factor of 0.8274 , the efficiency was calculated as $13.83 \%$. Compared to the above-mentioned solar cells, the efficiency is slightly improved $[19,20]$.

Now, a number of simulations were conducted for this particular device, with varying absorber layer thickness. The simulation outcomes are given in table 2.

As the rate of increase in cell efficiency drops at higher absorber thickness, simulations were not conducted for absorber thickness $>10 \mu \mathrm{m}$. The outcomes in table 2 give a number of thin film cell design options, each with considerably high efficiency. 
Table 2: Simulation outcomes with varying absorber thickness

\begin{tabular}{|c|c|c|c|c|}
\hline $\begin{array}{l}\text { Base } \\
\text { Thickness } \\
(\mu \mathrm{m})\end{array}$ & $\mathrm{J}_{\mathrm{sc}}$ & $\mathrm{V}_{\mathrm{oc}}$ & $\overline{F F}$ & $\eta(\%)$ \\
\hline 2 & 28.42 & 0.5882 & 0.8274 & 13.83 \\
\hline 3 & 29.58 & 0.5889 & 0.8251 & 14.37 \\
\hline 5 & 32.67 & 0.5908 & 0.8255 & 15.93 \\
\hline 8 & 34.94 & 0.5917 & 0.8257 & 17.07 \\
\hline 10 & 35.76 & 0.5917 & 0.8257 & 17.47 \\
\hline
\end{tabular}

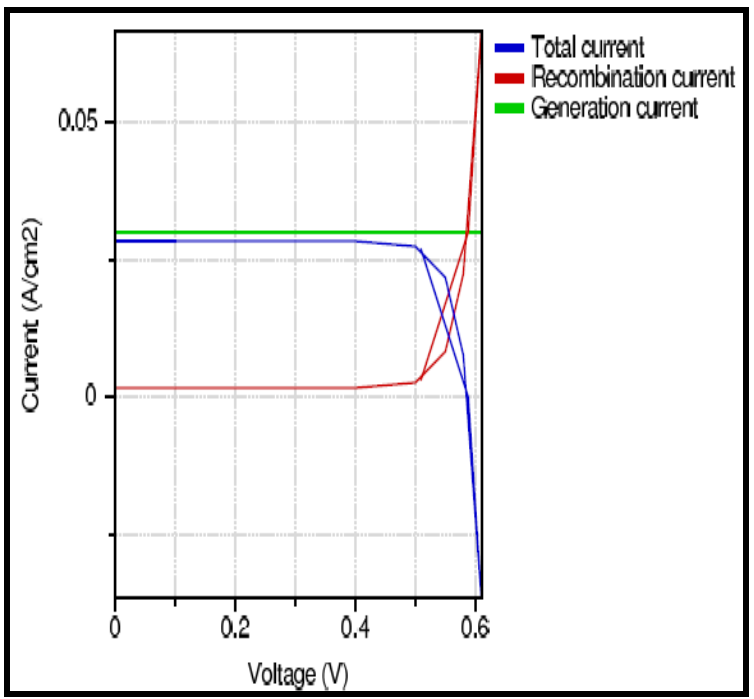

Fig. 2 Light J-V characteristics curve for the device with 2 $\mu \mathrm{m}$ absorber

A thicker base can absorb a greater number of photons, which improves the device output characteristics, including cell efficiency. This is supported by the results of table 2 . However, as the absorber becomes thicker, along with more efficient light absorption, electrical losses also increase in the solar cell. These two effects are contradictory, due to which the short-circuit current density $\left(\mathrm{J}_{\mathrm{sc}}\right)$ tends to reach a saturation value at higher absorber thickness. This phenomenon, previously observed in [21], is illustrated in figure 4. Now, the work done in [21] suggests that the opencircuit voltage $\left(\mathrm{V}_{\mathrm{oc}}\right)$ decreases with increasing absorber thickness. But the simulation results in table 2 show that the open-circuit voltage slightly increases with increasing absorber thickness, before it reaches saturation at higher absorber thickness values. This is illustrated in figure 5 .

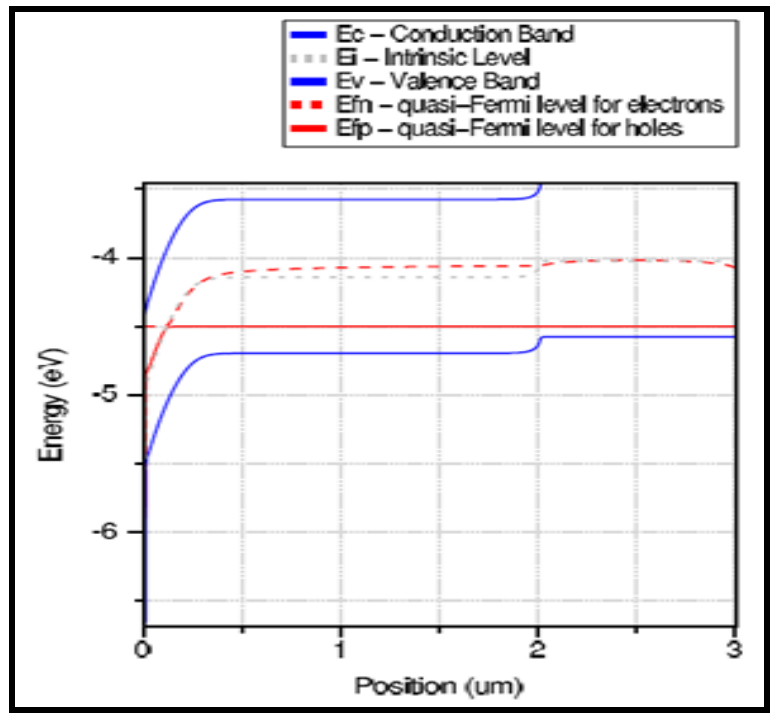

Fig. 3 Energy band diagram for the device with $2 \mu \mathrm{m}$ absorber

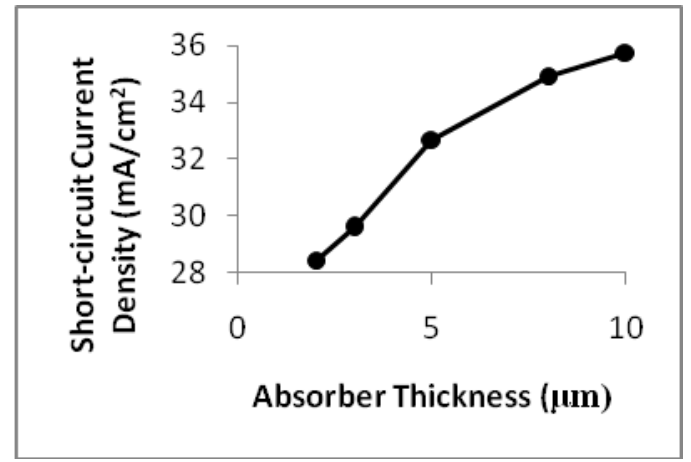

Fig. 4 Graph of short-circuit current density vs absorber thickness

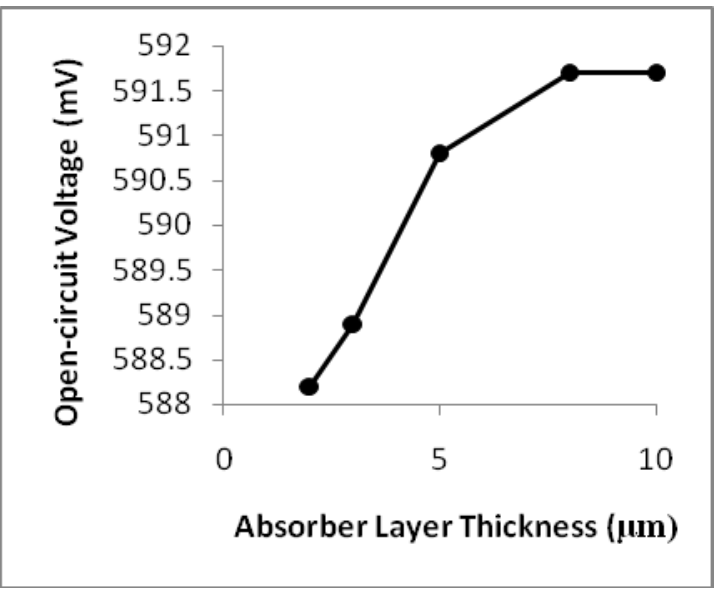

Fig. 5 Graph of open-circuit voltage vs absorber thickness 


\section{CONCLUSIONS}

This work presents a novel design of a thin film solar cell that integrates Silicon and III-V technology. The outcomes show slight improvement in short-circuit current density and efficiency, compared tothin film poly-Si solar cells on glass substrate. Using lattice-matched, high bandgap III-V and IIVI compounds as a window layer to form heterojunction with Si can open a new horizon for highly efficient, temperaturestable thin film solar cells.

\section{REFERENCES}

[1] Geoffrey A. Landis, "GaP/silicon Tandem Solar Cell with Extended Temperature Range", US Patent No. 7148417 (2006)

[2] M. Meyer and R.A. Metzger, "Flying high: The Commercial Satellite Industry Convert to Compound Semiconductor Solar Cells", Compound. Semiconductor, 2 (1996), pp. 22

[3] B. Garcia, Jr., "Indium Gallium Nitride Multijunction Solar Cell Simulation Using Silvaco Atlas", M. Sc. Thesis, Naval Postgraduate School, California, USA (2007)

[4] U. S. Department of Energy. (2011) Energy Basics. [Online] Available: http://www.eere.energy.gov/basics/renewable_energy/pv _cell_structures.html

[5] Peter Wurfel, "Physics of Solar Cells: From Principles to New Concepts", Wiley-VCH Verlag GmbH \& Co. KGaA, Weinheim, Germany (2005) pp. 3

[6] Ioffe Physical Technical Institute. (2005) NSM Archive Physical Properties of Semiconductors. [Online]. Available: http://www.ioffe.ru/SVA/NSM/Semicond/

[7] Md. Sharafat Hossain, Nowshad Amin, M. A. Matin, M. Mannir Aliyu, Takhir Razykov and Kamaruzzaman Sopian, "A numerical study on the prospects of high efficiency ultra thin $\mathrm{Zn}_{\mathrm{x}} \mathrm{Cd}_{1-\mathrm{x}} \mathrm{S} / \mathrm{CdTe}$ solar cell", Chalcogenide Lett. 8(2) (2011), pp. 263

[8] Lin Aiguo, Ding Jianning, Yuan Ningyi, Wang Shubo, Cheng Guanggui and Lu Chao, "Analysis of the $\mathrm{p}^{+} / \mathrm{p}$ window layer of thin film solar cells by simulation", J. Semicond. 33 (3) (2012) pp. 023002-1

[9] C. Lee, H. Efstathiadis, J. E. Raynolds and P. Haldar, "Two-dimensional Computer Modeling of Single Junction a-Si:H Solar Cells", Proc. 34th Photovolt. Specialists Conf., Philadelphia, USA (2009), pp. 1118
[10] J.W. Matthews, and A.E. Blakeslee, "Defects in epitaxial multilayers: I. Misfit dislocations", J. Cryst. Growth 27 (1974), pp. 118

[11] J. G. Fossum, "Physical operation of back-surface-field silicon solar cells," IEEE Trans. Electron Devices, 24(4) (1977), pp. 322

[12] T. Rachow, M. Ledinsky, S. Janz, S. Reber and A. Fezfer, " $\mu \mathrm{c}-\mathrm{Si}$ Solar Cells by Direct Deposition with APCVD", 27th Eur. PV Sol. Energy Conf. Exhib., Frankfurt, Germany (2012)

[13] J. L. Gray and Michael McLennan. (2008) Adept. [Online]. Available: http://nanohub.org/resources/adept/

[14] F. J. Morin and J. P. Maita, "Electrical Properties of Silicon Containing Arsenic and Boron", Phys. Rev.96 (1954), pp. 28

[15] M. S. Tyagi and R. Van Overstraeten, "Minority Carrier Recombination in Heavily Doped Silicon", Solid State Electron. 26(6) (1983), pp. 577

[16] M. A. Green, "Self-consistent optical parameters of intrinsic silicon at $300 \mathrm{~K}$ including temperature coefficients", Solar Energy Materials and Solar Cells, 92 (11) (2008), pp. 130

[17] Y. C. Kao and O. Eknoyan, "Electron and hole carrier mobilities for liquid phase epitaxially grown $\mathrm{GaP}$ in the temperature range 200-550 K, J. Appl. Phys. 54 (1983), pp. 2468

[18] M. A. Green, "Solar cell fill factors: General graph and empirical expressions," Solid-State Electron., 24(8) (1981), pp. 788

[19] K. Yamamoto, "Very thin film crystalline silicon solar cells on glass substrate fabricated at low temperature", IEEE Trans. Electron Devices 46 (10) (1999) pp.2041

[20] M. A. Green, K. Emery, Y. Hishikawa, W. Warta and E. D. Dunlop, "Solar cell efficiency tables (version 39)", Prog. Photovolt. Res. Appl. 20 (2012), pp. 12

[21] O. Vetterl, A. Lambertz, A. Dasgupta, F. Finger, B. Rech, O. Kluth and H. Wagner, "Thickness dependence of microcrystalline silicon solar cell properties", Sol. Energy Mater. Sol. Cells 66 (2001), pp. 345 